\title{
PENGARUH STRATEGI GO TO YOUR POST (BERGERAK KEARAH YANG DI PILIH) TERHADAP KEMAMPUAN MENULIS PUISI SISWA KELAS X SMA PRAYATNA MEDAN
}

\author{
Hera Chairunnisa \\ Universitas Negeri Medan \\ hera.chairunnisa@gmail.com
}

\begin{abstract}
Abstrak. Penelitian ini bertujuan untuk mengetahui apakah ada pengaruh Strategi pembelajaran Go To Your Post Kemampuan Menulis Puisi siswa Kelas X SMA Prayatna Medan. Populasi adalah siswa kelas X yang berjumlah 150 orang yang terdiri atas lima kelas sedangkan sampelnya adalah siswa kelas $\mathrm{X}$ yang berjumlah 60 yang terdiri atas dua kelas, dan dibagi menjadi dua kelompok yaitu kelompok kelas kontrol siswa kelas X-2 berjumlah 30 orang dan kelompok kelas eksperimen siswa kelas X-4 berjumlah 30 orang . Teknik menentukan sampel adalah Random Sampling. Metode yang digunakan dalam penelitian ini adalah metode eksperimen yaitu metode post-test only design group. Instrumen yang digunakan untuk menjaring data penugasan yakni menulis puisi. Dari hasil pengolahan data diperoleh rata-rata kelas eksperimen adalah 72,83, sedangkan rata-rata kelas kontrol adalah 61,83. Dengan demikian nilai kelas eksperimen lebih tinggi daripada kelas kontrol. Setelah dilakukan pengujian hipotesis diperoleh $\boldsymbol{t}_{\text {hitung }}=3,30$ pada taraf signifikan $\alpha=5 \%$ dari daftar distribusi dk 58, maka diperoleh $\boldsymbol{t}_{\text {tabel }}=2,002$. Jika harga $\boldsymbol{t}_{\text {hitung }}$ dibandingkan dengan harga $\boldsymbol{t}_{\text {tabel }}$ ternyata $\boldsymbol{t}_{\text {hitung }}>\boldsymbol{t}_{\text {tabel }}(3,30>2,002)$, dapat dinyatakan hipotesis nihil $\left(\mathbf{H}_{O}\right)$ ditolak dan hipotesis alternatif $\left(\mathbf{H}_{\boldsymbol{a}}\right)$ diterima. Berdasarkan analisis data dapat disimpulkan bahwa penggunaan strategi Go To Your Post dalam menulis puisi lebih berpengaruh dibandingkan dengan strategi pembelajaran Everyone is a teacher here. Kata Kunci : GoTo Your Post, Kemampuan Menulis Puisi
\end{abstract}

Abstract. This study aims to determine whether there is influence learning strategies Go To Your Post Ability Poetry Writing Class $\mathrm{X}$ high school student, SMA Prayatna Medan Terrain. The population is a tenth grade students totaling 150 people consisting of five classes while the sample were students of class $\mathrm{X}$ of 60 consisting of two classes, and are divided into two groups: the control class class $\mathrm{X}-2$ were 30 people and groups experimental class X-4 grade students numbered 30 people. Mechanical determine the sample is random sampling. The method used in this study is an experimental method is the method of post-test only design group. The instrument used to collect data which is writing poetry assignment. From the data processing obtained an average grade experiment is 72.83 , while the average grade control is 61.83. Thus the value of the experimental class is higher than the control class. After testing the hypothesis obtained $=3.30$ significance level $\hat{I}$ $\pm=5 \%$ of the distribution list $\mathrm{dk} 58$, the obtained $=2.002$. If the price compared with the price turns out> (3.30> 2.002), be declared null hypothesis ( is rejected and the alternative hypothesis) is accepted. Based on data analysis can be concluded that the use of strategies Go To Your 
Post in writing poetry is more influential than the learning strategies Everyone is a teacher here.

Keywords: Post Your GoTo, Poetry Writing Ability.

\section{PENDAHULUAN}

Pembelajaran bahasa Indonesia di sekolah memiliki empat keterampilan berbahasa yaitu keterampilan menyimak, berbicara, membaca, dan menulis. Berbicara dan menyimak merupakan kegiatan berbahsa lisan, sedangkan menulis dan membaca merupakan kegiatan berbahasa tulis. Sejak zaman dulu sebenarnya keterampilan menulis sudah dikuasai oleh nenek moyang kita sebagai media komunikasi. Media komunikasi dengan tulisan paling mudah didokumentasikan karena zaman dulu peradabannya belum maju dan belum ada alat perekam suara maka satu-satunya cara untuk menyampaikan pesan kepada orang lain hanya melalui tulisan. Pada zaman sekarang selain perekam suara, juga ada alat penyampai suara seperti telepon. Sebenarnya alat komunikasi manusia itu banyak, namun yang paling utama adalah bahasa, baik lisan maupun tulisan. Menulis dapat menumbuhkan keberanian. Banyak orang yang tidak menyampaikan gagasan dan pendapatnya secara langsung atau lisan, karena mereka takut keliru dan tidak percaya diri.

Menurut Suparno danYunus (2008:13) dalam Dalman (2014:4)" Menyatakan bahwa menulis merupakan suatu kegiatan penyampaian pesan (komunikasi) dengan menggunakan bahasa tulis sebagai alat untuk medianya".

Dalam pelajaran bahasa Indonesia, pada materi menulis puisi siswa diharapkan mampu mengekspresikan pemikiran atau pengamatan untuk menjadi sebuah puisi. Tanpa adanya bakat yang dimiliki dalam kemampuan menulis puisi siswa mampu asalkan siswa rajin belajar dan giat berlatih. Kemampuan menulis puisi sering dianggap sebagai bakat sehingga orang yang merasa tidak mempunyai bakat tidak dapat menulis puisi. Anggapan seperti itu tidak selalu benar karena kisah sejumlah sastrawan dapat menulis karena banyak berlatih.

Menurut KBBI (2001:903) "Puisi adalah ragam sastra yang bahasanya terikat oleh irama, matra, rima, serta penyusunan larik dan bait." Untuk dapat menciakan puisi, siswa harus menguasai struktur atau metode puisi yang terdiri atas diksi, imaji, majas, ritme, dan rima dan yang paling utama dalam menulis sebuah puisi sebaiknya menentukan tema terlebih dahulu.

Menulis puisi sebenarnya adalah pelajaran yang sangat menarik karena siswa dapat menuangkan perasaan atau gagasan dari hasil pemikiran yang kemudian ditulis menjadi tulisan indah dan memiliki makna yang baik. Tapi, pada kenyataannya siswa masih banyak yang kurang mampu menulis puisi dan memahami pelajaran menulis puisi. Seperti pada saat peneliti melaksanakan PPL-T di sekolah SMA Prayatna Medan. Selain kurang memahami, siswa kurang berminat untuk menulis puisi, karena metode atau strategi yang digunakan oleh guru bahasa Indonesia belum efektif sehingga dalam pelajaran menulis puisi siswa sering merasa bosan.Untuk mengatasi masalah tersebut agar tidak berkelanjutan maka guru perlu menerapkan strategi pembelajaran yang sesuai atau tepat sehingga dapat mengatasi permasalahan dalam meningkatkan aktivitas dan prestasi belajar Bahasa Indonesia siswa. Salah satu strategi pembelajaran yang dapat diterapkan dalam permasalahan adalah Go To Your Post.

Mel Silberman (2009:88), "Go To Your Post adalah sebuah strategi pembelajaran yang menggabungkan gerakan fisik pada permulaan suatu pelajaran". Strategi ini cukup fleksibel untuk digunakan bagi berbagai macam kegiatan yang dirancang untuk merangsang minat awal dalam materi pelajaran.

Berdasarkan permasalahan di atas maka peneliti termotivasi untuk melakukan penelitian dengan penerapan strategi pembelajaran go to your post. Penerapan strategi go to your post diharapkan dapat meningkatkan aktivitas siswa dalam pembelajaran Bahasa Indonesia sehingga prestasi belajar juga meningkat.

Go to your post ini sangat efektif terutama apabila kelompok siswa menghadapi kesulitan dalam membuat keputusan, seperti menentukan sebuah topik untuk diteliti melalui kerja 
Pengaruh Strategi Go To Your Post (bergerak ke arah yang dipilih) Terhadap Kemampuan Menulis Puisi Siswa Kelas X SMA Prayatna Medan

kelompok dan ketika mengalami kesulitan mencapai penyelesaian.

Berdasarkan permasalahan di atas, peneliti tertarik untuk melakukan penelitian dengan menggunakan strategi yang berjudul "Pengaruh Strategi GO TO YOUR POST (Bergerak Kearah Yang Di pilih) Terhadap Kemampuan Menulis Puisi Siswa Kelas X SMA Prayatna Medan."

\section{METODE PENELITIAN}

Adapun desain dalam penelitian ini menggunakan desain Post Test. Sedangkan metode yang digunakan dalam penelitian ini adalah metode eksperimen. Menurut Punaji Setyosari (2013:48) "Penelitian eksperimen menguji hubungan sebab akibat".

Adapun metodeeksperimen yang digunakan adalah eksperimen yang berpola post-test control group only design adalah desain yang menggunakan dua kelas dengan ketentuan satu kelas sebagai kelas eksperimen dankelas yang satu lagi sebagai kelas control. Sampel yang diambil dalam penelitian ini dikelompokan dalam dua kelompok dan diberi perlakuan berbeda, dimana kelas eksperimen diberi pengajaran strategi Go To Your Post terhadap kemampuan menulis puisi Sedangkankelompokkontroldiberipengajar anStrategi Everyone is a teacher here. Untuk lebih jelasnya rancangan penelitian seperti ini tertera di bawah ini :

Tabel 1. RancanganPenelitian

\begin{tabular}{|l|l|c|}
\hline Kelompok & \multicolumn{1}{|c|}{ Perlakuan } & $\begin{array}{c}\text { Post- } \\
\text { Test }\end{array}$ \\
\hline Eksperimen & $\begin{array}{l}\text { Go To Your Post } \\
\text { (bergerak kearah yang dipilih) } \\
\text { terhadapkemampuanmenulispuisi } \\
\text { (X4) }\end{array}$ & $\mathrm{T}$ \\
Kontrol & $\begin{array}{l}\text { Strategi Everyone is a teacher } \\
\text { here }(\mathrm{X} 2)\end{array}$ & $\mathrm{T}$ \\
\hline Keterangan \\
X4:Pembelajarandenganmenggunakan StrategiGo To Your \\
$\quad$ Post \\
X2: PembelajarandenganmenggunakanStrategi Everyone \\
is a Teacher here \\
T : TeskemampunMenulispisi
\end{tabular}

$\mathrm{T}$ : TeskemampuanMenulisPuisi

Instrumen Penelitian dan Teknik

Pengumpulan Data

\section{InstrumenPenelitian}

Tes merupakan instrument alat ukur sebagai teknik pengumpulan data adalah serangkai pertanyaan atau latihan yang digunakan untuk mengukur bakat dan kemampuan yang dimiliki individu. Instrumen yang digunakan yaitu berupa tes yang berupa soal esai.

Tabel 2. Kriteria Penilaian Menulis Puisi

\begin{tabular}{|c|c|c|c|c|}
\hline No. & $\begin{array}{c}\text { Aspek } \\
\text { Penilaian }\end{array}$ & Indikator & Skor & Jumlah \\
\hline \multirow[t]{3}{*}{1} & \multirow{3}{*}{$\begin{array}{l}\text { Diksi } \\
\text { Pemilihan } \\
\text { kata dalam } \\
\text { membuat } \\
\text { puisi }\end{array}$} & Jelas & 20 & \multirow{3}{*}{20} \\
\hline & & Kurang jelas & 15 & \\
\hline & & Tidak jelas & 10 & \\
\hline \multirow[t]{3}{*}{2} & \multirow{3}{*}{$\begin{array}{l}\text { Imajinasi } \\
\text { Penyampaian } \\
\text { imajinasi } \\
\text { dalam puisi }\end{array}$} & Jelas & 20 & \multirow{3}{*}{20} \\
\hline & & Kurang jelas & 15 & \\
\hline & & Tidak jelas & 10 & \\
\hline \multirow[t]{3}{*}{3} & \multirow{3}{*}{$\begin{array}{l}\text { Kata konkret } \\
\text { Memberikan } \\
\text { arti yang } \\
\text { sesungguhnya } \\
\text { dalam puisi }\end{array}$} & Jelas & 20 & \multirow{3}{*}{20} \\
\hline & & Kurang jelas & 15 & \\
\hline & & Tidak jelas & 10 & \\
\hline \multirow[t]{3}{*}{4} & \multirow{3}{*}{$\begin{array}{l}\text { Bahasa } \\
\text { figuratif } \\
\text { Pemilihan } \\
\text { Kata yang } \\
\text { bermakna }\end{array}$} & Jelas & 20 & \multirow{3}{*}{20} \\
\hline & & Kurang jelas & 15 & \\
\hline & & Tidak jelas & 10 & \\
\hline \multirow[t]{3}{*}{5} & \multirow{3}{*}{$\begin{array}{lr}\text { Rima } & \text { dan } \\
\text { ritme } & \text { Efek } \\
\text { bunyi } & \text { yang } \\
\text { indah } & \text { dalam } \\
\text { puisi } & \end{array}$} & Jelas & 20 & \multirow[t]{3}{*}{20} \\
\hline & & Kurang jelas & 15 & \\
\hline & & Tidak jelas & 10 & \\
\hline \multicolumn{4}{|c|}{ JUMLAH } & 100 \\
\hline
\end{tabular}

\section{TeknikAnalisa Data}

Setelah data diperoleh dilakukan analisis data dengan langkah-langkah sebagai berikut: Sudijono (2008)

1. Menyususn data post-test dalambentuktabel.

2. Menghitungnilai rata-rata skordarivariabelhasil post-test denganmengunakanrumus:

$$
\begin{aligned}
& M=\frac{\sum \mathrm{f}_{\mathrm{x}}}{N} \\
& \text { Keterangan: } \\
& \mathrm{M} \quad: \text { rata-rata (mean) } \\
& \sum f_{x} \quad: \text { jumlah frekuensi } \\
& N \quad: \text { jumlah sampel }
\end{aligned}
$$

3. Menghitung standar deviasi dari variable hasil post-test dengan menggunakan rumus:

$$
\begin{aligned}
& S D=\sqrt{\frac{\sum f x^{2}}{N}} \\
& \text { Keterangan: } \\
& \begin{array}{ll}
\text { SD } & : \text { standardeviasi } \\
N x^{2} & : \text { jumlah kuadrat nilai frekuensi } \\
N & : \text { jumlah sampel }
\end{array}
\end{aligned}
$$

4. Menghitung standar error dari variabel hasil post-test dengan menggunakan rumus:

$$
\begin{aligned}
& S D_{M}=\frac{S D}{\sqrt{N-1}} \\
& \text { Keterangan: } \\
& \mathrm{SD} \quad: \text { standardeviasi } \\
& \mathrm{SE}_{\mathrm{M}} \quad: \text { standar error } \\
& \mathrm{N} \quad: \text { jumlahsampel }
\end{aligned}
$$


Pengaruh Strategi Go To Your Post (bergerak ke arah yang dipilih) Terhadap Kemampuan Menulis Puisi Siswa Kelas X SMA Prayatna Medan

5. Setelah hasil standar error kelompok sampel diperoleh, maka langkah terakhir dari standar error adalah mencari perbedaan hasil standar error pada kedua kelompok (eksperimen dan kelompok) dengan menggunakan rumus:

$$
S E_{M 1-M 2}=\sqrt{S E_{M 1}{ }^{2}+S E_{M 2}{ }^{2}}
$$

\section{UjiNormalitas}

(Sudjana, 2005) menyatakan bahwa "Uji normalitas dilakukan untuk mengetahui apakah populasi berdistribusi normal atau tidak".Uji normalitas dilakukan dengan menggunakan uji Lilifor dengan langkah-langkah sebagai berikut:

a. Data $X_{1}, X_{2}, \ldots \ldots X_{n}$ dijadikan bilangan baku $Z_{1}, \quad Z_{2}, \ldots \ldots \ldots Z_{n}$ dengan menggunakan rumus $Z_{1}=\frac{\mathrm{x}_{1}-\overline{\mathrm{x}}}{\mathrm{s}}$

dan $\mathrm{S}$ masing-masing merupakan ratarata dan simpangan baku sampel).

b. Untuk tiap bilangan baku ini menggunakan daftar distribusi normal baku kemudian dihitung peluang dengan rumus $\left(\mathrm{Z}_{1}\right)=\mathrm{P}\left(\mathrm{z} \leq \mathrm{z}_{\mathrm{i}}\right)$

c. Selanjutnya dihitung proporsi $Z_{1}$, $Z_{2}, \ldots \ldots . Z_{n}$ yang lebih kecil atau sama dengan $Z_{i}$ jika proporsi ini dinyatakan oleh $\mathrm{S}\left(\mathrm{z}_{\mathrm{i}}\right)$, maka :

$S\left(Z_{1}\right)=\frac{\text { banyaknya } \mathrm{z}_{1}, \mathrm{z}_{2 \ldots \ldots} \mathrm{z}_{\mathrm{n}}}{\mathrm{n}}$

d. Dihitung selisih $F\left(z_{i}\right)-S\left(z_{i}\right)$ kemudian tentukan harga mutlaknya, dan

e. Ambil harga yang paling besar diantara harga-harga mutlak selisih tersebut (Lo).

7. Uji Homogenitas

Uji homogenitas bertujuan untuk mengetahui apakah data mempunyai varians yang homogeny atau tidak.Pengujian homogenitas dengan uji Bartlet dengan formula sebagai berikut:

$$
\begin{aligned}
& X^{2}=\left(\text { In 10) }\left(\mathrm{B}-\sum(n i-1) \log S_{i}^{2}\right)\right. \\
& \text { Keterangan: } \\
& \begin{array}{ll}
\mathrm{B} & =\text { Koefesien Bartlet } \\
\mathrm{S}_{\mathrm{i}}^{2} & =\text { Varians dari kelompok lebih besar } \\
n_{\mathrm{i}}-1 & =\text { Derajat kebebasan tiap kelompok }
\end{array}
\end{aligned}
$$

8. Uji hipotesis

Uji hipotesis penelitian dilakukan dengan menggunakan uji " $t$ " dengan rumus sebagai berikut:(sudijno, 2008:

$$
\mathrm{t}=\frac{\overline{\mathrm{x}} 1-\overline{\mathrm{x}} 2}{\mathrm{~S} \sqrt{\frac{1}{\mathrm{n}_{1}}+\frac{1}{\mathrm{n}_{2}}}}
$$

Selanjutnya adalah mencari harga $\mathrm{t}$ pada table (t test), pada tingat kepercayaan $(\alpha) 5 \%$. Berdasarkan $t_{\text {tabel }}$ dapat ditentukan bahwa:

1. Ho diterima apabila harga $t_{\text {hitung }}\left(t_{h}\right) \leq$ $\mathrm{t}_{\text {tabel }}\left(\mathrm{t}_{\mathrm{t}}\right)$ yang sekaligus menolak Ha.

2. Ha diterimaapabila harga $t_{\text {hitung }}\left(t_{h}\right)$ $>t_{\text {tabel }}\left(t_{t}\right)$ yang sekaligus menolak Ho.

\section{HASIL PENELITIAN}

\section{Analisis Data Kelas Eksperimen}

Berdasarkan nilai kemampuan menulis puisidiatas, diperoleh penyebaran nilai 50 sampai 95. Berdasarkan tabel diatas dapat diketahui nila rata-rata hasil belajar kemampuan menulis puisidengan menggunakan strategi go to your postyaitu total nilai dibagi jumlah siswa (sampel), yaitu $2185: 30=72,83$. Dengan demikian, hasil kemampuan menulis puisi dengan menggunakan strategi go to your postpada kategori baik yaitu dengan nilai rata-rata 72,83 .

\section{Analisis Data Kelas Kontrol}

Berdasarkan nilai kemampuan menulis puisidi atas, diperoleh penyebaran nilai 50 sampai 80 .Berdasarkan tabel di atas dapat diketahui nilai rata-rata hasil belajar kemampuan menulis puisi dengan menggunakan strategi pembelajaran Everyone is a teacher hereyaitu total nilai dibagi jumlah siswa (sampel), yaitu $1855: 30=61,83$. Dengan demikian, hasil kemampuan menulis puisidengan menggunakan strategi pembelajaran Everyone is a teacher herepada kategori baik yaitu dengan nilai rata-rata 61,83 .

\section{Uji Persyaratan Analisi Data}

1. Uji Normalitas

Berdasarkan hasil analisis didapat $\mathrm{L}_{\text {hitung }}=0.0983$ dengan menggunakan $\alpha=$ 0.05 dan $\mathrm{N}=30$, maka nilai kritis melalui uji Lillifors diperoleh $\mathrm{L}_{\text {tabel }}=0.161$ Ternyata $\mathrm{L}_{\text {hitung }}<\mathrm{L}_{\text {tabel }}(0.0983<0.161)$ ini membuktikan bahwa data kelas eksperimen berdistribusi normal. Sedangkan berdasarkan hasil analisis didapat $\mathrm{L}_{\text {hitung }}=0.0729$ dengan menggunakan $\alpha=0.05$ dan $\mathrm{N}=30$, maka nilai kritis melalui uji Lillifors diperoleh $\mathrm{L}_{\text {tabel }}=0.161$ Ternyata $\mathrm{L}_{\text {hitung }}<\mathrm{L}_{\text {tabel }}$ $(0.0729<0.161)$ ini membuktikan bahwa data kelas eksperimen berdistribusi normal.

2. UjiHomogenitas

Dari hasil analisis diperoleh $\mathrm{X}^{2}$ hitung (chi kuadrat) sebesar 3,453 harga $\mathrm{X}^{2}$ tabel pada taraf 
Pengaruh Strategi Go To Your Post (bergerak ke arah yang dipilih) Terhadap Kemampuan Menulis Puisi Siswa Kelas X SMA Prayatna Medan

kepercayaan 5\% dengan dk 29 adalah 43,773.Ternyata $\mathrm{X}^{2}$ hitung $<\mathrm{X}^{2}$ tabel yaitu $3,453<43,773$. Hal ini membuktikan bahwa varians populasi adalah homogeni.

3. Uji Hipotesis

Dari hasil analisis diperoleh $t_{\text {hitung }}$ $=3,30$ selanjutnya disesuaikan dengan $\mathrm{t}_{\text {tabel }}$ pada taraf signifikan $5 \%$ dengan $\mathrm{dk}=($ $\left.\mathrm{n}_{1}+\mathrm{n}_{2}\right)-2=(30+30-2)=58$, maka diperoleh taraf signifikan $5 \%=2,002$ (dengan interpolasi). Kemudian dibandingkan antara $t_{\text {hitung }}$ dengan $t_{\text {tabel }}$ diperoleh $t_{\text {hitung }}>t_{\text {tabel }} 3,30>2,002$ sehingga dapat disimpulkan bahwa hipotesis diterima.

Go To Your Post dalam kemampuan menulis puisi lebih signifikan berpengaruh dibandingkan dengan strategi pembelajaran Everyone is a teacher here.

\section{PEMBAHASAN}

Setelah melakukan prosedur penelitian yang panjang, misalnya dengan melakukan analisis data, kemudian melakukan hipotesis, akhirnya penelitian mendapatkan hasil yang tidak sia-sia. Pengaruh strategi pembelajaranGo To Your Post dalam meningkatkan kemampuan menulis puisi ternyata berpengaruh positif dan lebih baik dari pada hasil belajar dengan menggunakan strategi Everyone is a teacher here.Hal ini dapat dibuktikan pada hasil penelitian yaitu nilai rata-rata kemampuan menulis puisi dengan menggunakan strategi pembelajaran Go To Your Post lebih tinggi yakni sebesar 72,83 daripada nilai rata-rata kemampuan menulis puisi dengan menggunakan strategi Everyone is a teacher here yakni sebesar 61,83. Berdasarkan pengujian normalitas dan homogenitas, maka diketahui bahwa data pada kedua kelas yakni kelas kontrol dan kelas eksperimen berdistribusi normal dan mempunyai variansi sama. Berdasarkan hasil analisis data dengan menggunakan uji t diperoleh $t_{\text {hitung }}=3,30$ pada taraf signifikan $\mathrm{a}=5 \%$ dari daftar distribusi $\mathrm{t} \mathrm{dk}$ 58, maka diperoleh $t_{\text {tabel }}=2,002$. Jikaharga $t_{\text {hitung }}$ dibandingkan dengan harga $t_{\text {tabel }}$ ternyata $t_{\text {hitung }}>t_{\text {tabel }}$ $(3,30>2,002)$, dapat dinyatakan hipotesis nihil $\left(\mathrm{H}_{O}\right)$ ditolak dan hipotesis alternatif $\left(\mathrm{H}_{a}\right)$ diterima, maka strategi pembelajaran Go To Your Post mempunyaipengaruh dalam meningkatkan kemampuan siswa terhadap menulis puisi. Setelah didapat hasil dari penelitian ini, selanjutnya akan dibahasmengenai mengapa strategi pembelajaran Go To Your Postlebih baik dibandingkan dengan strategi Everyone is a teacher here. Hal ini dapat dijelaskan bahwa penerapan strategi pembelajaran Go To Your Postadalah sebuah strategi pembelajaran yang menggabungkan gerakan fisik pada permulaan suatu pelajaran". Strategi ini cukup fleksibel untuk digunakan bagi berbagai macam kegiatan yang dirancang untuk merangsang minat awal dalam materi pelajaran.Jadi, hasil belajar dengan menggunakan strategi pembelajaran Go To Your Post lebih baik dari pada hasil belajar dengan menggunakan strategi pembelajaran Everyone is a teacher here.

\section{SIMPULAN}

Berdasarkan hasil penelitian yang telah diuraikan, maka dapat disimpulkan :

1. Pemerolehan rata - rata kemampuan menulis puisi siswa kelas X SMA Prayatna medan dengan menggunakan strategi go to your postadalah 72,83 pada kategori Baik.

2. Pemerolehan rata - rata kemampuan menulis puisi siswa kelas X SMA Prayatna medan dengan menggunakan strategi Everyone is a teacher here adalah 61,83 pada kategori Kurang.

3. Dari hasil pengolahan data diperoleh rata - rata kelas eksperimen adalah 72,83dengan standar deviasi 15,52, sedangkan rata - rata kelas kontrol 61,83 dengan standar deviasi 11,49. Dengan demikian dapat dikatakan bahwa nilai kelas eksperimen lebih tinggi dari kelas kontrol. Setelah dilakukan pengujian hipotesis diperoleh $t_{\text {hitung }}=3,30$ selanjutnya dikonsultasikan dengan $t_{\text {tabel }}$ pada taraf signifikan 5\% dengan $\mathrm{dk}=\left(\mathrm{n}_{1}+\mathrm{n}_{2}\right)-2$ $=(30+30-2)=58$, maka diperoleh taraf signifikan $5 \%=2,002$ (dengan interpolasi). Kemudin dibandingkan antara $t_{\text {hitung }}$ dengan $t_{\text {tabel }}$ diperoleh $t_{\text {hitung }}$ $>t_{\text {tabel }} 3,30>2,002$ sehingga dapat disimpulkan bahwa hipotesis diterima yaitu menyatakan bahwa strategi go to your post mempunyai pengaruh dalam meningkatkan kemampuan siswa dalam menulis puisi.
SARAN 
Pengaruh Strategi Go To Your Post (bergerak ke arah yang dipilih) Terhadap Kemampuan Menulis Puisi Siswa Kelas X SMA Prayatna Medan

Berdasarkan pembahasan dan kesimpulan dari hasil penelitian di atas, maka penulis memberikan beberapa saran sebagai berikut :

1. Guru bahasa Indonesia hendaknya harus sering menerapkan strategi strategi pembelajaran yang inovatif dan kreatif agar siswa dengan mudah memahami materi yang diajarkan.

2. Salah satu strategi pembelajaran yang dapat diterapkan guru dalam menulis puisi adalah strategi go to your post. Hal ini sesuai dengan pembahasan hasil penelitian, terlihat bahwa strategi go to your post mampu menciakan semangat dan motivasi siswa dalam menulis puisi.

3. Penerapan strategi go to your postperlu adanya kontrol yang baik oleh guru pada saat siswa melakukan latihan menulis puisi sehingga siswa benarbenar memanfaatkan waktu dan memahami materi dengan baik.

4. Perlu dilakukan penelitian lanjut oleh peneliti lain guna memberi masukan yang konstruktif bagi dunia pendidikan khususnya dalam meningkatkan kemampuan siswa dalam menulis puisi.

\section{DAFTAR PUSTAKA}

Al- Quran surah Al- Mujadalah.

Arikunto,S.2006. Evaluasi Penelitian. Jakarta : Bumi Aksara.

Arikunto,S 2012. Dasar - Dasar Evaluasi, Edisi Dua. Jakarta : Bumi Aksara.

Arikunto,S 2002. Prosedur Penelitian Suatu Pendekatan, Jakarta : Rineka Cipta.

Arikunto,S 2010. Prosedur Penelitian Suatu Pendekatan Praktik, Jakarta : Rineka Cipta.

Sudjana, 2002. Metode Statistika, Bamdung : Tarsito.

Sudjono, Anas. 2010. Pengatur Statistik Pendidikan, Jakarta : Rajawali Pers.

Sugiyono, 2011. Statistika Untuk Penelitian, Bandung : Alfabeta.

Sugiyono ,2013. Metode Penelitian Pendidikan, Bandung : Alfabeta.
Setyosari, 2013. Metodologi penelitian. Jakarta : Kencana Prenada Group.

Sudjana,2002. Metode Statiska. Bandung : Tarsito. 